\title{
Sociedades Científicas Brasileiras
}

Todos aqueles que trabalham na área de Química, seja na indústria, em Institutos de Pesquisa ou em Instituições de Ensino tem oportunidade de participar de uma associação que congregue interesses comuns, que permita a seus associados terem encontros periódicos e discussões científicas.

$\mathrm{Na}$ área de Química, a maior associação que abrange diversas divisões é a Sociedade Brasileira de Química (SBQ), responsável pela publicação do Journal of Brazilian Chemical Society e Química Nova. Em maio p.p., a SBQ realizou na Cidade de Poços de Caldas, Minas Gerais, a $23^{a}$ Reunião Anual da Sociedade Brasileira de Química tendo como tema central "Brasil 500 - a Ligação Química Brasil/Portugal". O total de trabalhos inscritos foi 1537 ,

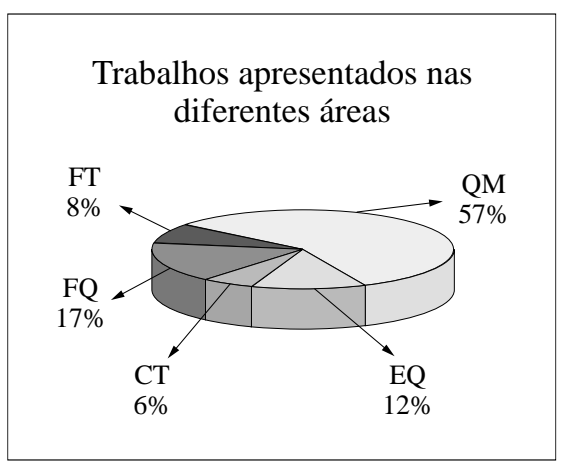

poliméricos caracterizaram-se por apresentar um excelente nível e permitir a discussão entre os pesquisadores e alunos de pós-graduação, predominando pesquisadores de Instituições de Ensino Superior público e privado, com um reduzido número de participantes da indústria. A participação da indústria química e de produtos relacionados é importante e deve ser incentivada de maneira que venha a estreitar o distanciamento entre a pesquisa realizada em Institutos de Pesquisa e a de interesse específico na solução de problemas, redução de custos, qualificação e desenvolvimento de novos produtos. Este é um processo lento cujos resultados não são necessariamente imediatos, exigindo uma colaboração mútua Indústria-Universidade.

Com o objetivo de fortalecer esse intercâmbio e de aumentar o número de participantes foi, recentemente, criada a Regional Sul da Associação Brasileira de Polímeros (ABPol). Desta maneira não estaríamos criando uma nova sociedade, cujos membros em potencial seriam os mesmos que já participam da SBQ ou ABPol, mas aproximando os atuais e despertando o interesse de outros participantes da comunidade universitária ou de setor industrial da região sul.

Notícia elaborada pelo Prof. Alfredo Tibúrcio Nunes Pires do Departamento de Química, Universidade Federal de Santa Catarina. 